Malgozhata Kaminska

ORCID iD 0000-0002-1643-3949

PhD (Humanities, Pedagogy), Assistant Professor at the Faculty of Pedagogy, Paweł Włodkowic University College in Płock, 12 Jana Kilińskiego al., 09-402 Plock, Poland, gosiam0@poczta.onet.pl

\title{
STANDARDS OF QUALITY OF LIFE FOR PEOPLE WITH DISABILITIES IN THE EUROPEAN UNION'S POLICY
}

The image of disability in EU societies is changing. On the one hand, statistical data (global and European) indicate an increase in the number of people with disabilities. This is especially true for women, the elderly and the poor. On the other hand, numerous legislative and implementation activities are undertaken to implement the social model in the approach to disability issues. The effectiveness of social and economic policies in the EU member states is expressed by the quality of life of people with disabilities. The article presents the WHO global position on the disability problem and a brief comparative analysis of key statistical data characterising people with disabilities in the EU member states. The EU priorities regarding the standards of functioning of people with disabilities in the objective and subjective dimensions are discussed. The source of the EU's strategy and activities are international documents: The Convention on the Rights of Persons with Disabilities of 2006 and the Council of Europe Disability Action Plan.

Key words: disability; European Union; quality of life; standards.

https://doi.org/10.28925/1609-8595.2020.1.15

Introduction. According to data from the World Health Organization (WHO), over one billion people with disabilities live around the world, which is about $15 \%$ of the world's population, in other words - every seventh inhabitant of the Earth is disabled. Of this number, between 110 million and 190 million adults experience significant difficulties in functioning. It is estimated that approximately 93 million children - or one in 20 children under the age of 15 - live with moderate or severe disabilities. The number of disabled people will grow as societies age and the incidence of chronic diseases increases. National patterns of disability are influenced by trends in health, environmental and other factors such as traffic accidents, falls, violence, humanitarian disasters, including natural disasters and conflicts, unhealthy diets and abuse of addictive substances. Disability is disproportionately affecting women, the elderly and the poor (WHO global disability action plan, 2014, p. 47). People with disabilities face numerous barriers in accessing services such as health care (including medical care, treatment and assistive technologies), education, employment and social assistance, including housing and transport. (...) These barriers cause obstacles that people with disabilities experience. Especially in developing countries, people with disabilities have worse health than healthy people, and they also have a higher rate of poverty, lower education and employment, reduced independence and limited participation (WHO global disability action plan, 2014, p. 48).

The World Health Organization (WHO) recognises disabled people as people who are unable, partly or completely, to provide for independent individual and social life as a result of congenital or acquired impairment of physical or mental health. Until now disability, as a consequence of illness or injury, was considered from the medical point of view. It was perceived as a unitary problem of a person requiring proper medical care, aimed at improving the health and functioning of the body. On the other hand, psychosocial aspects of real life problems of people with disabilities, such as the removal of barriers limiting the possibility of their participation in social life, were not fully taken into account (WilmowskaPietruszyńska, Bilski, 2014, p. 20). For a long time, there was no document on an international scale that would refer to the whole of the problems of the functioning of people with disabilities. In 2006, the UN Convention on the Rights of Persons with Disabilities was adopted, where persons with a disability were considered persons with long-term, reduced physical, mental, intellectual or sensory fitness, which in interaction with various barriers may limit their full and effective participation in society on an equal basis with other citizens (The Convention on the Rights of Persons with Disabilities, 2006). Therefore, it is not the disability itself that can be an obstacle in various aspects of human life, but the clash of its impairment with barriers and obstacles resulting from the maladjustment of the socio-cultural environment and its conditions. Person with impairment may become disabled. He/she becomes it if he/she encounters barriers limiting or preventing him/her from performing social roles (including professional ones) in the same way as other people. Let us remind that impairment is any loss of fitness or an abnormality in the construction or 
functioning of the body in psychological, psychophysical or anatomical terms. Disability - any limitation or inability (resulting from impairment) to lead an active life in a manner or in a range considered to be typical for a human being. Limitations in performing social roles (handicap) - disability of a specific person resulting from disability or impairment, limiting or preventing full implementation of the social role corresponding to age, gender and in accordance with social and cultural conditions (Wilmowska-Pietruszyńska, Bilski, 2014, p. 24).

Disability is not just a simple biological or social phenomenon. WHO views disability as a global public health problem in the context of human rights and development priorities. Disability is a global public health problem, because disabled people throughout their lives are struggling with common barriers to access health services and other related to them, such as rehabilitation, are in a worse state of health than fully functional people. Some health conditions can also be risk factors for other health problems, often neglected, such as increased obesity in people with Down syndrome and diabetes or colorectal cancer in people with schizophrenia. Disability is also a human rights issue because adults, young people and children with disabilities experience stigmatisation, discrimination and inequality; they are the object of many violations of their rights, including their dignity, for example as a result of acts of violence, abuse, prejudice and disrespect due to their disability; and they are also deprived of autonomy. Disability is a development priority due to the higher incidence of it in low-income countries and because of mutual reinforcement and consolidation of disability and poverty. Poverty increases the likelihood of disorders resulting from malnutrition, inadequate health care and unsafe lifestyle, work and travel conditions. Disability can lead to a decrease in the standard of living and poverty through lack of access to education and employment, and through increased disability-related expenses (WHO global disability action plan, 2014, p. 45).

The purpose of the article - to characterize standards of quality of life for people with disabilities in the European Union's policy.

People with disabilities in the European Union - a review of statistical surveys. In the European Union, one in six people is disabled, ranging from mild to significant, which means that around 80 million Europeans are often unable to fully participate in social and economic life due to environmental barriers and attitudes of their environment. The poverty rate of people with disabilities is $70 \%$ higher than the average, also due to limited access to employment. Over one third of people over 75 years have a disability that limits their capabilities to a certain extent, and over $20 \%$ of these limitations are significant. The aging process of the EU society affects the systematic increase of this number (Communication from the Commission to the European Parliament, 2010, p. 3). The research carried out in 20082009 shows that the situation of people with disabilities in individual countries is significantly diversified. For example, in 2009, the share of people with disabilities in the population above 16 years of age was the lowest in such countries as: Malta, Spain, Sweden, Bulgaria, Italy, Cyprus, Greece. The highest rate in this respect was recorded in Slovakia, Germany, Portugal, Finland and Latvia. The highest increase in this percentage during the year was found in Finland, the largest decrease - in Italy (by over 10\%). In Poland, the percentage of the disabled was lower in relation to the EU average (25.5\%) and amounted to $23.1 \%$ (Figure 1).

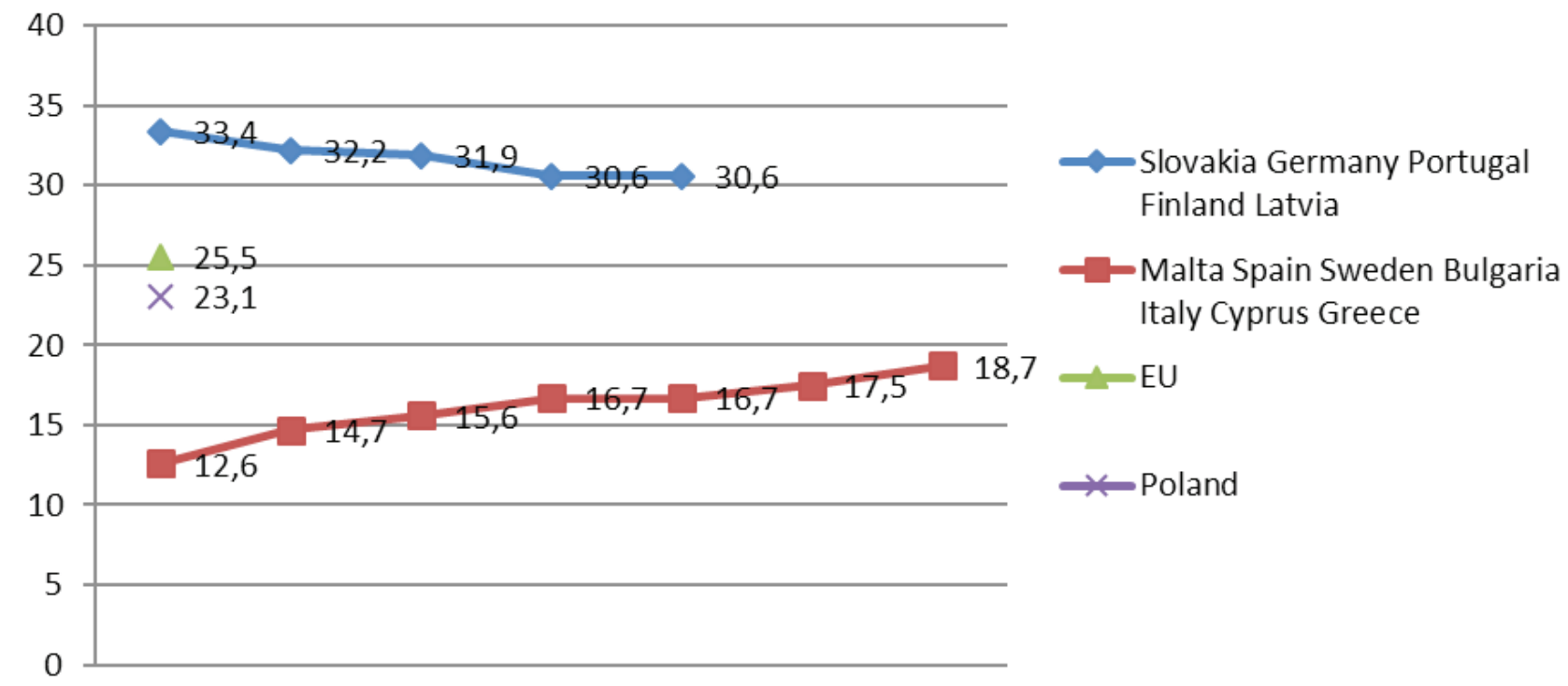

Figure 1. Participation of people with disabilities above 16 years of age EU countries with the highest and lowest percentage (2009)

Source: E. Kryńska (ed.), 2013, p. 15. 
The percentage share of women with disabilities in 2009 was $5.1 \%$ higher than for men (in Poland 3.3\%). In half of the countries, the percentage of women with disabilities was higher than the EU average (27.9\%), among others in: Slovakia, Portugal, Latvia, Germany. On the other hand, the lowest rate was achieved by such countries as: Malta, Cyprus, Sweden, Bulgaria (Fig. 2).

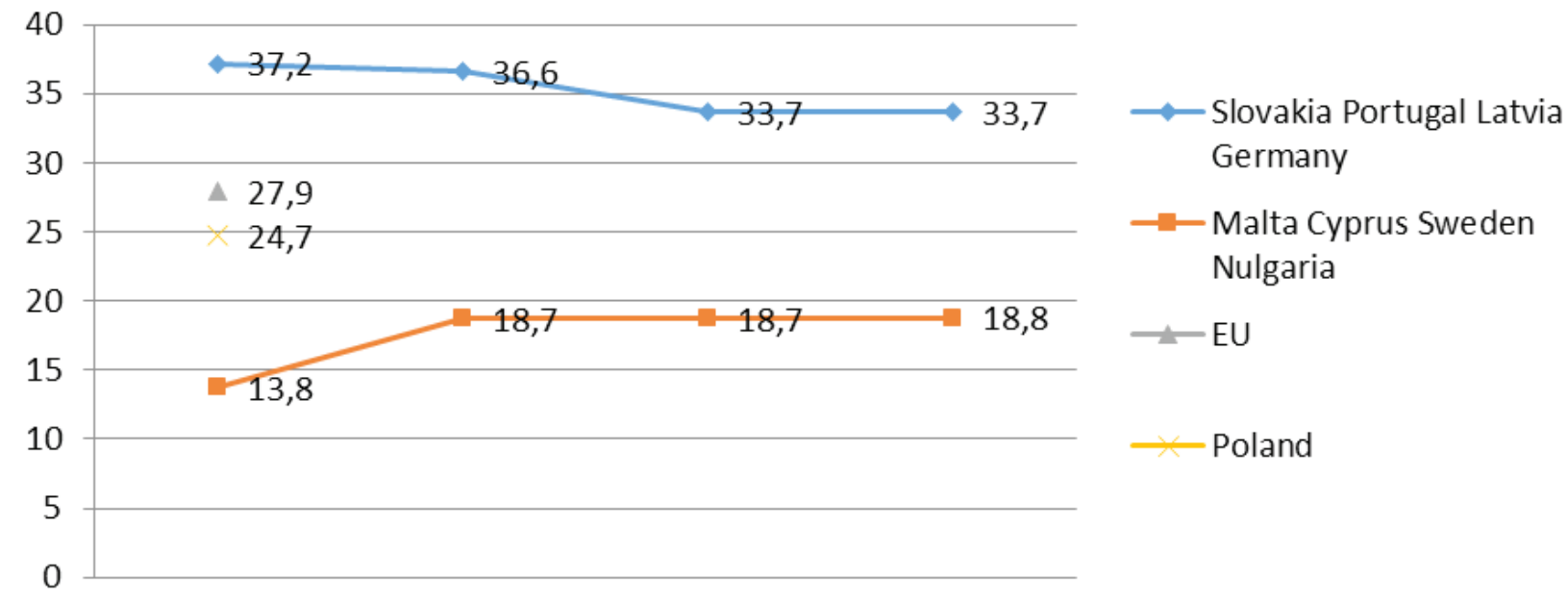

Figure 2. Participation of women among people with disabilities EU countries with the highest and lowest percentage (2009)

Source: E. Kryńska (ed.), 2013, p. 15.

In terms of age - in EU countries - a definitely higher percentage of people with disabilities was recorded in the age group of 65 and more $-54.6 \%$ (during the year an increase of $0.3 \%$ ). However, in the $16-64$ age group it was $17.6 \%$ and during the year the situation did not change. The largest indicator among seniors with disabilities was found, among others in Slovakia, Estonia, Portugal,
Latvia. The smallest percentage was recorded in Sweden, Denmark and Malta. In the age group 16-64, the percentage was definitely the lowest in Greece, Malta, Bulgaria, Cyprus and Sweden. The highest rates were recorded in Finland, Slovakia, Germany and Denmark. In Poland, percentage in both age groups was close to the EU average (Fig. 3 and 4).

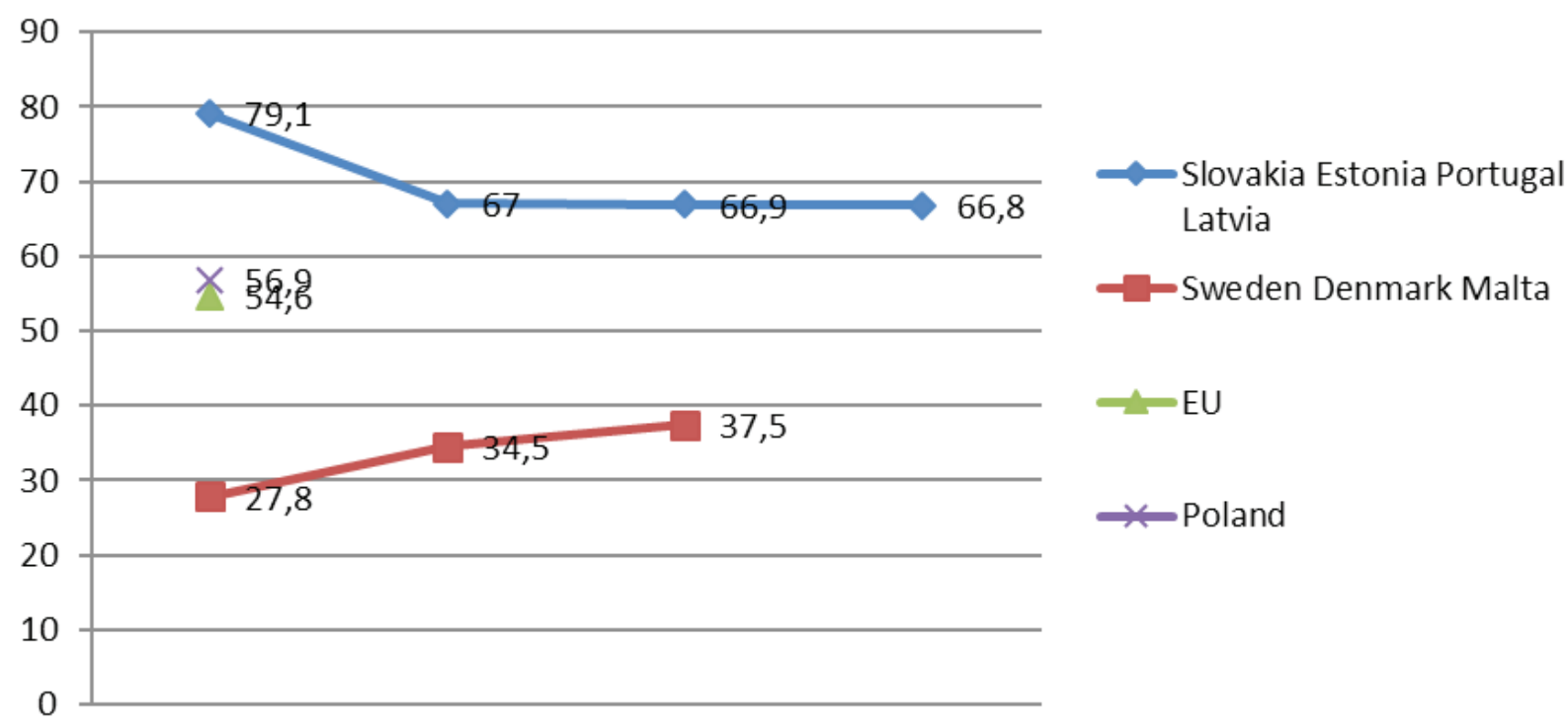

Figure 3. Participation of people with disabilities that are 65 or more EU countries with the highest and lowest percentage (2009) Source: E. Kryńska (ed.), 2013, p. 17. 


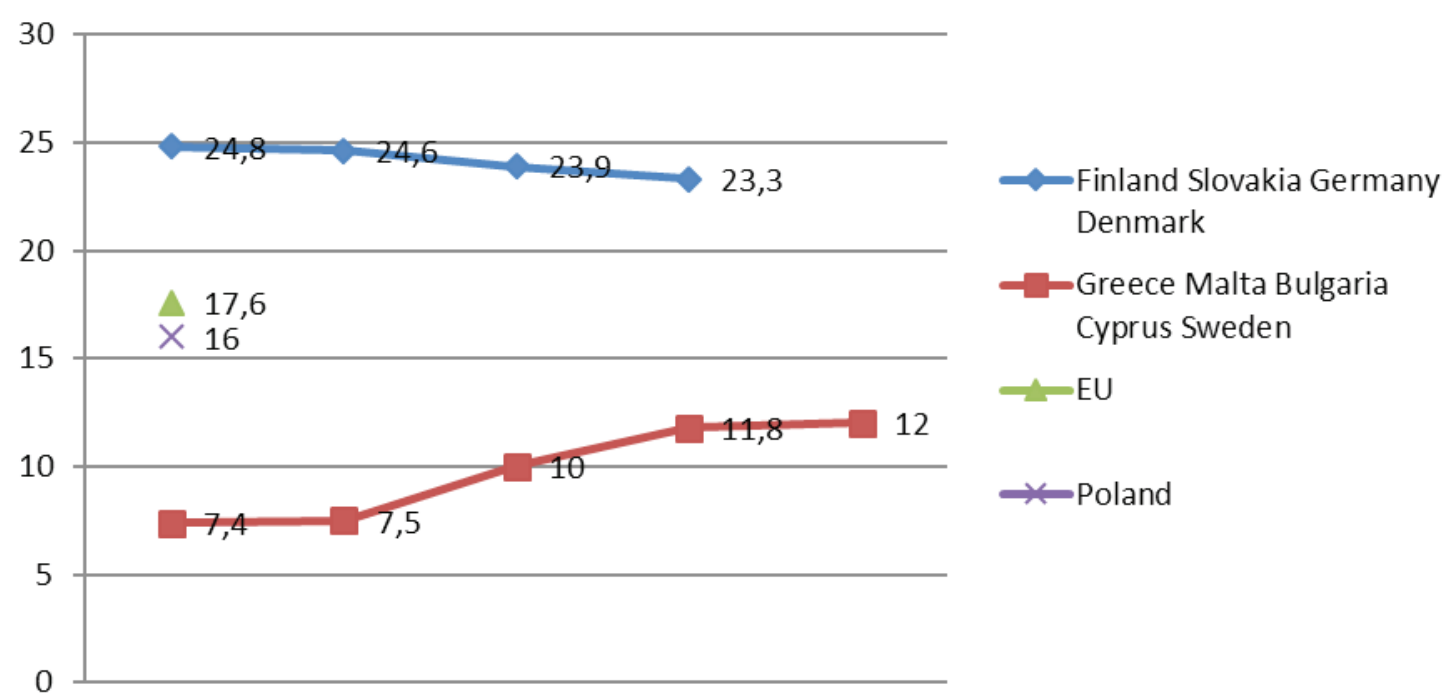

Figure 4. Participation of people with disabilities aged 16-64EU countries with the highest and lowest percentage (2009) Source: E. Kryńska (ed.), 2013, p. 17.

The average rate of professional activity among people with disabilities aged 20-64 in the EU countries in 2009 was $55.5 \%$ and was $0.7 \%$ higher than in 2008 . In Poland, this indicator in 2009 reached a slightly lower rate $-38.7 \%$. However, it grew by $1.1 \%$ during the year. The highest percentage of professionally active people in the aforementioned population of people with disabilities was recorded in Germany, Denmark, Finland, Slovenia and Latvia. The lowest level of economically active people was observed in such countries as: Romania, Greece, Poland, Malta, Ireland (Fig. 5).

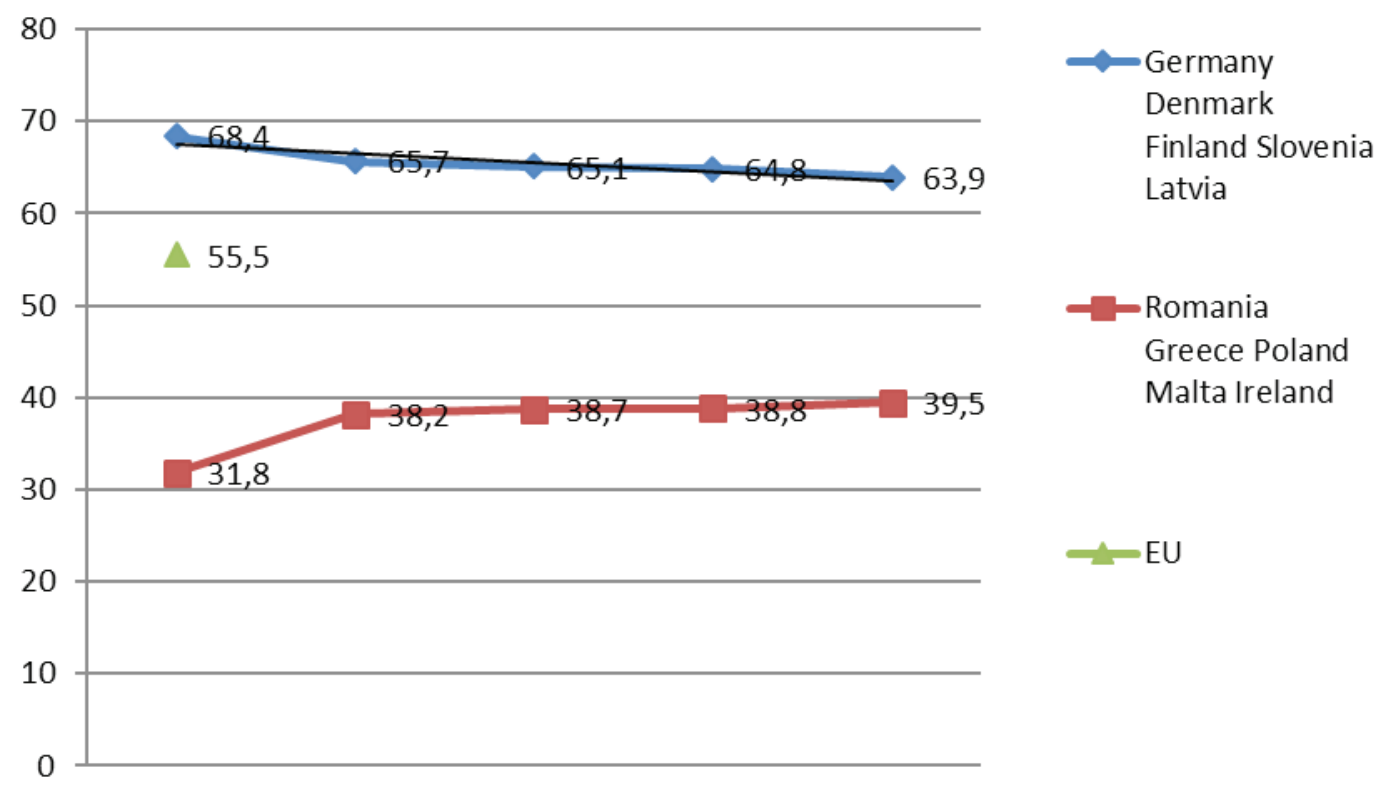

Figure 5. Professional activity of people with disabilities aged 20-64EU countries with the highest and lowest percentage (2009)

Source: E. Kryńska (ed.), 2013, p. 39-40.

In many European countries people with disabilities cannot fully implement their professional plans due to limited ability. The average employment rate in the
European Union in 2009 was $45.7 \%$. The highest rate was achieved by such countries as: Denmark, Luxembourg, Finland, Netherlands, Germany. Definitely lower rates 
were recorded in Ireland, Romania, Greece, Malta and Hungary. Poland also ranked lower than the EU average $-33.3 \%$ (Fig. 6).

Based on the above analysis of statistical data, it can be concluded that the situation of people with disabilities in the European Union is not satisfactory. The percentage of such people increases due to, among others, factors such as the systematic aging of the European population, chronic diseases, unhealthy lifestyle. There are countries in Europe where statistical indicators are worrying, e.g. Slovakia, Germany, Portugal, Latvia and Finland. Despite many initiatives and undertakings, the quality of life of people with disabilities, especially seniors, women and poor people, deviates from the norms and standards adopted in the socio-cultural environment of non-disabled people.

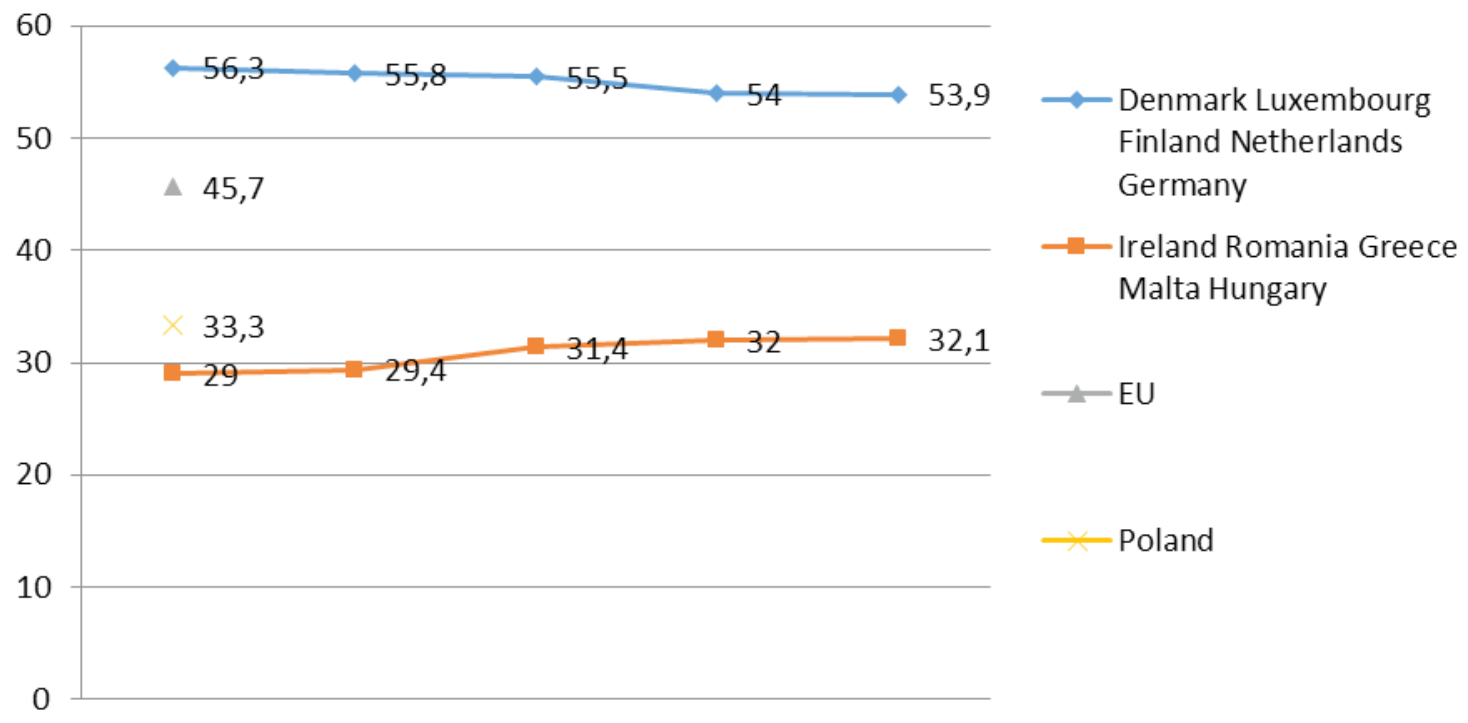

Figure 6. Employment of people with disabilities aged 20-64EU countries with the highest and lowest percentage (2009) Source: E. Kryńska (ed.), 2013, p. 41-40.

The quality of human life. Many authors agree that quality of life has a dichotomous structure. It consists of both so-called objective and subjective quality. This division is reflected in the definition of the World Health Organization (WHO). Quality of life is an «individual's perception of their position in life in the context of the culture and value systems in which they live and in relation to their goals, expectations and standards set by their environment» (Objective and subjective quality of life of adults with intellectual disabilities, 2014, p. 9). Ja. Daszykowska (2010) cites the description of the concept of quality of life after M. Wallden, «determined by the possibilities of meeting the needs and aspirations by social groups and individuals. At the level of social groups, the quality of life is treated in terms of goals and values, while the quality of human life is determined by the conditions that comprise the physical and cultural environment, resources and social opportunity to meet needs and aspirations» (p. 51). Objective and subjective elements of the quality of life are characterised by A. Zawiślak (2006), based on the views of H. Sęk and A. Firkowska - Mankiewicz: «Objective ones include macroeconomic conditions, such as the political, legal and economic system of the state or social and mesostructural policy, i.e. the functioning of social institutions, administrative and municipal services. In addition, factors concerning the conditions and the level of human life, his social position, education, structure and state of the organism. In turn, the subjective quality of life refers to the processes of evaluation, that is, the assessment and well-being of the individual in all spheres of his/her own existence». In the concept of quality of life by D. Felce and J. Perry, there are three levels: 1. Personal values, 2. Personal life satisfaction, 3. Objective living conditions. Personal values are good physical condition (health, mobility, efficiency, safety), good financial status (earnings, housing, communication, social security), good social status (personal relationships, social bonds, support), good emotional state (positive emotions, mental health, resistance to stress, leisure), development and activity (competence, productivity, self-esteem, faith, sex). Objective living conditions determine the realisation of personal values, which can affect the achievement of personal life satisfaction by an individual (Daszykowska, 2010, pp. 51-52). These personal values are of course subjectively assessed by the individual and the relationship between all three levels may vary depending on how a person perceives, for example, a good physical, material, social, emotional state, level of development and activity. This is due to 
Campbell's (1976) study, which stated «the lack of a clear correlation between the objective parameters of quality of life and the level of satisfaction with it. It cannot be assumed that an objective improvement in the quality of life is accompanied by an increased sense of happiness (success, satisfaction). In many cases, dissatisfaction with objective conditions seems to increase during the same period in which these conditions are improved in every respect and according to all criteria; this discrepancy is of great social and political implications» (after: Sompolska-Rzechuła, 2013, p. 133). Referring to the issue of the quality of life of people with disabilities and its shaping factors, reference can be made to the 2002 report, in which R. Schalock, I. Brown, R. Brown, R.A. Cummins, D. Felka, L. Matikka, K. Keith and T. R. Parmenter assumed that the quality of life:

1. contains the same factors and relationships for both people with and without disabilities (non-disabled),

2. is experienced when an individual can strive to achieve goals in a family, social and professional environment on equal conditions,

3 . is composed of subjective and objective elements, but the way of perceiving the quality of life by a person is considered most important,

4 . is based on values that are especially important for a given person,

5. is a multidimensional construct,

6 . is constituted by both personal and environmental factors; relationships: family, friendly, neighbouring, local; education, health status, standard of living, nationality (Objective and subjective quality of life of adults with intellectual disabilities, 2014, p. 11).

Structural determinants of the quality of life of people with disabilities. The statistical data presented earlier on the situation of people with disabilities in the EU indicate that the level of quality of life may vary depending on such factors as: gender, age, occupational activity, employment. In the World Report on Disability 2011, a number of up-to-date information on overcoming the barriers faced by disabled people in accessing health services, rehabilitation, support and assistance, their environment (such as buildings and transport), education and employment can be found. In the opinion of WHO experts, «the reasons for these barriers are, for example, inadequate legislation, policies and strategies; no benefits; problems with their delivery; lack of knowledge and understanding of disability; negative attitudes and discrimination; lack of availability; insufficient financial resources and lack of participation in decision-making that have a direct impact on the lives of people with disabilities» (WHO global disability action plan, 2014, p. 48).

It seems that in the EU countries the following are of particular importance: legal arrangements, implementation of policies and long-term strategies. The inspiration for their creation and implementation are often the documents of international institutions - the Council of Europe and the United Nations. In the Council of Europe Disability Action Plan from 2006, the most important guidelines for improving the quality of life of people with disabilities in Europe in 2006-2015 were taken into account. Recommended actions cover all key areas of life of people with disabilities. Those facilities include: 1. Participation in political and public life, 2. Participation in cultural life, 3. Information and communication, 4. Education, 5. Employment, counselling and vocational training, 6. Building environment, 7. Transport, 8. Living in a local community, 9. Healthcare, 10. Rehabilitation, 11. Social protection, 12. Legal protection, 13. Protection against violence and exploitation, 14. Research and development, 15. Raising awareness. Cross-sectional aspects related to the prevention of double discrimination in the case of women, children and adolescents, elderly people and people from minority communities and from migrants exposed to a higher risk of exclusion are also included. The main elements of the strategy of implementing the Action Plan for disabled people are the principles of Universal Design, quality, training and an integrated approach. Applying the principles of Universal Design is essential to increase the availability of the environment and the usability of products. Policies, activities and services should be characterised by a high standard in terms of quality. Moreover, the mainstream approach in policymaking plays an important role in promoting a more integrated society. The basic assumption is also to change the way of thinking about persons with disabilities (from the patient to the citizen), i.e. abandoning the medical model in favour of a model based on social rights and human rights (The Council of Europe Disability Action Plan, 2006, pp. 4-12).

The directions of action indicated in the above Action Plan refer directly to the UN Convention on the Rights of Persons with Disabilities adopted in 2006. It contains basic norms and standards related to the functioning of people with disabilities in the social, cultural and economic space. The EU signed the UN Convention on the Rights of Persons with Disabilities on the opening day for signature, i.e. on 30 March 2007. The convention has so far been signed by all 27 Member States (2012 in Poland) and by 120 countries in the world. As a result of the completion of the ratification procedure, for the first time in history, the EU as a whole became a party to the UN treaty (Łajdych, 2011). The Convention ensures and obliges the Parties (States) to comply with generally accepted standards in the field of human rights, including equality and non-discrimination; the right to life; protection and safety in emergency situations; equality before the law and access to justice; the right to liberty and security of a person; the right to information and privacy. It also introduces standards relevant to the quality of life of people with disabilities, such as raising public awareness; accessibility - on an equal basis with other citizens - to the physical environment, transport, information and interpersonal communication, including communication and information technologies and 
systems, and to other facilities and services offered to the whole society, both in urban and rural environments; the right to independent living and social integration; the right to mobility; providing access to facilities for full and equal participation in education and social life; the right to the highest possible standard of health and revalidation and rehabilitation; the right to work and employment according to the will of the disabled person in an open, non-exclusive working environment. Attention is also paid to providing people with disabilities and their families with adequate living conditions, including adequate food, clothing and housing, and to continuously improve living conditions, the right to social protection; the possibility of full and effective participation in public, political and cultural life; the right to personal development and the use of their creative, artistic and intellectual potential, not only for their own benefit, but also for the enrichment of society (The Convention on the Rights of Persons with Disabilities, 2006).

Europe without barriers. In the 2010 the European Commission presented the European Disability Strategy 2010-2020 to the European Parliament, the Council, the European Economic and Social Committee and the Committee of the Regions: A renewed commitment to build Europe without barriers in 2010. It indicates the purposefulness of using the combined potential of the EU Charter of Fundamental Rights, the Treaty on the Functioning of the European Union and the UN Convention and the full use of the «Europe 2020» strategy and its instruments. The intention of the creators of the strategy was first of all to improve the quality of life of disabled people, increase their opportunities so that they can participate fully in social life and in the European economy, especially thanks to the uniform market. The proposed joint actions and mechanisms were to make it easier for EU member states to effectively implement the Convention on the Rights of Persons with Disabilities.

The key assumption of the strategy is to build a barrier-free Europe. The postulates concern such areas of activity as: 1. Availability, 2. Participation, 3. Equality, 4. Employment, 5. Education and training, 6. Social protection, 7. Health. Most of the proposed activities refer to the problems diagnosed in the reports presented above. The determinant of activities are high standards of the quality of life of people with disabilities determined by the level and scope of macro- and microstructural conditions. In social policy, particular attention is paid to environmental care systems (instead of institutional ones), development of personal care financing systems, provision of appropriate careers for carers, support for families and informal carers, standardisation of mobility and communication rights. In the area of employment, diversity management in the workplace is promoted, as well as the issue of self-employment and good quality jobs, in terms of working conditions and career development. Equality and accessibility is manifested, among others in healthcare and social protection standards. People with disabilities have the right to equal access to health care, including prevention, and to special high-quality health and rehabilitation services at affordable prices that take into account their needs, including those related to gender. Disabled people must be able to use social protection systems and poverty reduction programs, help in disability areas, social housing and other services that increase their capabilities, as well as pension and disability programs.

Conclusions. The pursuit of continuous improvement of the quality of life standards of people with disabilities is a consequence of demographic changes and the growing number of such people in the societies of Europe and the world. It also results from the adopted model of social perception of disability. As B. Gąciarz (2014) writes, «disability is a relative feature resulting primarily from the nature of the interaction between a given person and the environment in which he/she is and acts. Obtaining fitness means enabling a given person to effectively implement their actions despite their damages and losses in psychosomatic functions. To achieve this, changes should be made in the material environment, in the construction of institutional mechanisms to ensure effective support for people with disabilities, as well as in social behaviour patterns towards people with various types of disabilities or impairments» (p. 21). The quality of life of people with disabilities in the European Union depends to a large extent on the social, economic and cultural policy of individual member states. Strategies and activities assume a clear focus on preventing discrimination, promoting equality in access to services, education and employment. An important aspect of policies towards people with disabilities is the implementation of the idea of social integration by creating a legal system that responds to the real needs and expectations of the disabled people. This is facilitated by the vision of a person with disability as a fully-fledged citizen who actively participates in political, social and economic life.

\section{References}

Daszykowska, J. (2010). Jakość życia w perspektywie pedagogicznej [Quality of life from a pedagogical perspective]. Impuls.

Gąciarz, B. (2014). Model społeczny niepełnosprawności jako podstawa zmian w polityce społecznej [The social model of disability as the basis for changes in social policy]. In B. Gąciarz B., S. Rydnicki (Eds.) Polscy niepetnosprawni. Od kompleksowej diagnozy do nowego modelu polityki spotecznej [Polish disabled people. From a comprehensive diagnosis to a new model of social policy] (pp. 17-43). Wydawnictwo Akademii Górniczo-Hutniczej.

Communication from The Commission to The European Parliament, The Council, The European Economic and Social Committee and The Committee of the Regions. European Disability Strategy 2010-2020: A renewed commitment 
to build Europe without barriers (2010). https://www.rpo.gov.pl/pl/content/europejska-strategia-w-sprawieniepełnosprawnosci-0.

The Convention on the Rights of Persons with Disabilities (2006). http://www.unic.un.org.pl/dokumenty/ Konwencja_Praw_Osob_Niepelnosprawnych.pdf.

Kryńska, E. (Ed.) (2013). Analysis of the situation of disabled people in Poland and the European Union. Institute of Labour and Social Affairs.

Łajdych, N. (2011). The EU ratified the UNConvention on the Rights of Persons with Disabilities. http://uniaeuropejska. org/ue-ratyfikuje-konwencje-onz-o-prawach-osob-niepelnosprawnych/.

Recommendation Rec(2006)5 of the Committee of Ministers to Member States on the Council of Europe Action Plan to promote the rights and full participation of people with diabilities in society: improving the quality of life of people with diabilities in Europe 2006-2015. https://rm.coe.int/1680595206

W HO global disability action plan 2014-2021 «Better health for all people with disability» (2014). Niepetnosprazoność - zagadnienia, problemy, rozwiazania, IV (13), 42-72.

Objective and subjective quality of life of adults with intellectual disabilities living in the Greater Poland Voivodeship. Environmental conditions and the level of support for social policy implementers. Research report (2014). Regional Centre for Social Policy in Poznań. https://rops.poznan.pl/badania-spoleczne/raporty-z-badan/badania-2014.

Sompolska-Rzechuła, A. (2013). Quality of life as an economic category. Folia Pomeranae Universitatis Technologiae Stetinensis, Oeconomica, 301 (71), 127-140.

Wilmowska-Pietruszyńska, A., Bilski, D. (2014). International Classification of Functioning, Disability and Health. Orzecznictwo Lekarskie, 9 (1), 19-27.

Zawiślak, A. (2006). Theoretical dilemmas regarding taking into account the subjective aspects of the quality of life of people with intellectual disabilities. In Cz. Kosakowski, A. Krause, S. Przybyliński (Eds.), Dyskursy pedagogiki specjalnej. Pomiędzy teoria a praktyka [Discourses of special education. Between theory and practice], vol. V, pp. 77-82. Wydawnictwo Uniwersytetu Warmińsko-Mazurskiego w Olsztynie.

\title{
СТАНДАРТИ ЯКОСТІ ЖИТТЯ ЛЮДЕЙ 3 ОБМЕЖЕНИМИ МОЖЛИВОСТЯМИ В ПОЛІТИЦІ ЄВРОПЕЙСЬКОГО СОЮЗУ
}

\author{
Камінська Малгожата, \\ PhD з гуманітарних наук у галузі педагогіки, \\ викладач у Вищій школі імені Павла Влодковіца у Плоцьку, \\ ал. Яна Кілінського, 12, 09-402 Плоцьк, Польща, \\ gosiam0@poczta.onet.pl
}

Імідж інвалідності в суспільствах СС змінюється. 3 одного боку, статистичні дані (глобальні та європейські) свідчать про збільшення кількості людей з обмеженими можливостями. Особливо це стосується жінок, літніх та бідних. Люди з обмеженими можливостями стикаються з численними бар'єрами у доступі до таких послуг, як охорона здоров'я (включаючи медичну допомогу, лікування та допоміжні технологіï), освіту, зайнятість та сочіальну допомогу, включаючи житло та транспорт. На національну закономірність інвалідності впливають тендениї в галузі охорони здоров'я, екологічних та інших факторів, таких як дорожньо-транспортні пригоди, насильство, гуманітарні катастрофи, включаючи стихійні лиха та конфлікти, нездорові дієти та зловживання наркотичними засобами. 3 іншого боку, проводяться численні законодавчі та виконавчі заходи для впровадження сочіальної моделі y підході до питань інвалідності. Ефективність соціальної та економічної політики в країнах-членах ЕС виражається якістю життя людей з обмеженими можливостями, яка в свою чергу залежить від таких факторів, як: стать, вік, професійна діяльність, зайнятість. Якість життя людей з обмеженими можливостями в Європейському Союзі значною мірою залежить від сочіальної, економічної та культурної політики окремих країн-членів. У статті представлено глобальну позицію ВООЗ щодо проблеми інвалідностітакороткий порівняльний аналіз ключовихстатистичних даних, щохарактеризуютьлюдей з обмеженими можливостями в країнах-членах ЄС. Обговорюються пріоритети ЄС щодо стандартів функціонування людей з обмеженими можливостями в об'єктивних та суб'єктивних вимірах. Джерелом стратегї та діяльності ЄС є міжнародні документи: Конвенція про права людей з інвалідністю 2006 року та План дій Ради Свропи щодо інвалідності.

Ключові слова: люди з обмеженими можливостями; Свропейський Союз; стандарти; якістьжиття. 


\title{
СТАНДАРТЫ КАЧЕСТВА ЖИЗНИ ЛЮДЕЙ С ОГРАНИЧЕННЫМИ ВОЗМОЖНОСТЯМИ В ПОЛИТИКЕ ЕВРОПЕЙСКОГО СОЮЗА
}

\author{
Каминская Малгожата, \\ $\mathrm{PhD}$ по гуманитарным наукам в области педагогики, \\ преподаватель в Высшей школе имени Павла Влодковиц в Плоцке, \\ ал. Яна Килинского, 12 09-402 Плоцк, Польша, \\ osiam0@poczta.onet.pl
}

Имиджинвалидностив обществах ЕСменяется. Соднойстороны, статистическиеданные (глобальные и европейские) свидетельствуют об увеличении количества людей с ограниченными возможностями. Особенно это касаетсяженщин, пожилыхи бедных. Людис ограниченными возможностямисталкиваются с многочисленными барьерами в доступе к таким услугам, как здравоохранение (включая медицинскую помощь, лечение и вспомогательные технологии), образование, занятость и социальная помощь, включая жилье и транспорт. На национальную закономерность инвалидности влияют тенденции в области здравоохранения, экологических и других факторов, таких как дорожно-транспортные происшествия, насилие, гуманитарные катастрофы, включая стихийные бедствия и конфликты, нездоровые диеты и злоупотребления наркотическими средствами. С другой стороны, проводятся многочисленные законодательные и исполнительные меры для внедрения социальной модели в подходе к вопросам инвалидности. Эффективность социальной и экономической политики в странах-членах ЕС выражается качеством жизни людей с ограниченными возможностями, которая в свою очередь зависит от таких факторов, как пол, возраст, профессиональная деятельность, занятость. Качество жизни людей с ограниченными возможностями в Европейском Союзе в значительной степени зависит от социальной, экономической и культурной политики отдельных стран-членов. В статье представлены глобальная позииия ВОЗ по проблеме инвалидности и короткий сравнительный анализ ключевых статистических данных, характеризующих людей с ограниченными возможностями в странах-иленах ЕС. Обсуждаются приоритеты ЕС относительно стандартов функиионирования людей с ограниченными возможностями в объективных и субъективных измерениях. Источником стратегии и деятельности ЕС являются международные документы: Конвенция о правах людей с инвалидностью 2006 года и План действий Совета Европы по инвалидности.

Ключевые слова: Европейский Союз; качество жизни; люди с ограниченными возможностями; стандарты. 